\title{
Renaissance Painting and Expressions of Male Intimacy in a Seventeenth-Century Illustration from Mughal India
}

\author{
MIKA NATIF
}

The George Washington University

This article explores the artistic relationship between Western European Renaissance art and Mughal painting ca. 1630s at the ateliers in North India. A central theme is the employment of European painterly modes in the Mughal visual tradition that expressed male-male intimacy, carnal desire, and emotional attachment. In particular, the article focuses on the work of the Mughal painter Govardhan, who illustrated the opening scene of Sa'dìs Gulistan (Rose Garden). Govardhan built upon sixteenth-century European compositional elements and the themes of Noli me tangere and the Doubting Thomas to form subtle yet unmistakable allusions to male-male sexuality.

Cet article explore les relations artistiques entre lart de la Renaissance européenne et la peinture moghole des années 1630 dans les ateliers du nord de l'Inde. On y traite de l'utilisation de motifs de la peinture européenne dans la tradition visuelle moghole exprimant l'intimité masculine, le désir charnel et l'attachement affectif. Cet article se penche en particulier sur l'ouvre du peintre mogol Govardhan qui a illustré la scène d'ouverture du Gulistan (Rose Garden) de Sa'dì. Govardhan y a construit son illustration à l'aide lélément de composition de l'Europe du XVIe siècle, ainsi que sur les thèmes Noli me tangere et du Thomas incrédule, afin de créer une évocation subtile mais univoque de la sexualité homosexuelle masculine.

$\mathrm{T}$ he relationship between Mughal India and early modern Europe has long been a source of interest to historians focusing on the complex connections between East and West. ${ }^{1}$ Indeed, since the end of the sixteenth century, a growing European presence at the courts of India and the Mughal elite's openness to, or curiosity about, other traditions resulted in fascinating artistic creations. One such example is a painting of a bare-breasted, Europeanlooking woman reclining on a lavish carpet in a garden while nursing a baby

1. See for example Michael North, ed., Artistic and Cultural Exchanges between Europe and Asia, 1400-1900 (Burlington, VT: Ashgate, 2010); Gauvin Alexander Bailey, The Jesuits and the Grand Mogul: Renaissance Art at the Imperial Court of India, 1580-1630 (Washington, DC: Freer Gallery of Art, Arthur M. Sackler Gallery, Smithsonian Institution, 1998); Jorge Manuel Flores and Nuno Vassallo e Silva, eds., Goa and the Great Mughal (Lisbon: Calouste Gulbenkian Foundation, 2004); Sanjay Subrahmanyam, Mughals and Franks: Explorations in Connected History (New York: Oxford University Press, 2012).

Renaissance and Reformation / Renaissance et Réforme 38.4, Fall / automne 2015 
(Figure 1). ${ }^{2}$ Reminiscent of images of the Virgin and Child, this Mughal picture elicits the erotically charged subtext in Christian images. Dressed in European garb with heavy folds, the beautiful woman is depicted with her round full white breasts exposed, while a small baby suckles at her side. She reclines lazily on a Mughal golden carpet, with her eyes almost closed, while a pavilion of some sort is shown in the background. Exhibiting discursive practices at the Mughal workshop in terms of Indo-Persian and European technique and subject matter, the painting represents the amalgamation of notions of the erotic "other" imbued with the physical beauty and religious imagery of the Madonna.

Notable developments were undertaken to better showcase the idiosyncratic fusion of Mughal and European traditions in an allegorical painting by the court artist Bichitr (active ca. 1610-60) of Jahangir Preferring a Sufi Shaykh to Kings (Figure 2). ${ }^{3}$ In this picture, the Mughal emperor is represented sitting on an elaborate hourglass throne, handing a book to an elderly shaykh (a Muslim religious leader and scholar). However, the complex composition is studded with European elements and features. We may notice pairs of putti hovering above and below the ruler, a stand decorated with golden statues of Greek or Roman mythological creatures, a tapestry in the background with a classical, grotesque-like pattern, and a portrait of England's King James I in the lower left corner. All of these elements come together to create a cross-cultural cosmopolitan mélange of symbols, styles, and ideas. ${ }^{4}$

By the time Bichitr created this picture (ca. 1615-18), the meeting between European art and Mughal painting was possible because various European traders, envoys, and missionaries had arrived on the Indian subcontinent during the second half of the sixteenth century and settled, by and large, in the southwest coastal area. ${ }^{5}$ These Portuguese, Spaniards, and Italians, some of whom were

2. Virgin and Child, ca. 1599-1600, from the Jahangir Album (1610), opaque watercolor and gold on paper. The San Diego Museum of Art, \#1990.293.

3. The painting is from the so-called St. Petersburg Album and is signed by Bichitr. Made in Mughal India, ca. 1615-18, opaque watercolor, ink, and gold on paper. Freer Gallery of Art F1942.15, Washington, DC.

4. For an in-depth analysis of this painting, see Richard Ettinghausen, “The Emperor's Choice," in De Artibus Qpuscula X: Essays in Honor of Erwin Panofsky, ed. Millard Meiss (New York: New York University Press, 1961), 98-120.

5. Much has been written on the subject of European settlements in India. Here are just a few examples: Om Prakash, European Commercial Enterprise in Pre-Colonial India, The New Cambridge History of India (Cambridge; New York: Cambridge University Press, 1987); Sanjay Subrahmanyam, The 
Jesuit missionaries, had brought with them luxury objects such as books, engravings, prints, and paintings that created a myriad of opportunities in terms of commercial, intellectual, and artistic exchanges. ${ }^{6}$ These opportunities were translated, among other things, into visual expressions as Mughal artists and patrons remoulded the different artistic traditions presented in European works of art. ${ }^{7}$ It took the Mughals' self-confidence, and a curiosity and openness, for these ideas to foster porous artistic interactions with a variety of traditions. ${ }^{8}$

From the Mughal perspective, the meeting of these diverse artistic traditions brought about new possibilities for expressing the personal, carnal, and emotional aspects of the depicted figures. The sophistication with which these new idioms were designed merits further attention. At the focal point of this essay stands the Mughal painter Govardhan's illustration of the opening scene of Sadì's Gulistan (Rose Garden) (Figure 3). ${ }^{9}$ Govardhan (active ca. 1596-1645) was a court artist at the service of the Mughal emperors and produced most of his work in the ateliers of Jahāngīr and Shāh Jahān, ${ }^{10}$ while the author Sa'di lived and worked in Shiraz in the thirteenth century. Due to the popularity of his work, Sa'dīs Gulistan was copied numerous times. The illustration by Govardhan appears in a luxurious manuscript that has a complicated history. It was produced initially in 1468-69 at the royal Timurid workshop in Herat, transported first to Safavid Iran (1501-1722) and later to the Mughal royal

Portuguese Empire in Asia, 1500-1700: A Political and Economic History (London; New York: Longman, 1993); Subrahmanyam, Mughals and Franks.

6. On some of the luxury objects that the Portuguese and the Jesuits brought to India, see Flores and Silva, eds., Goa and the Great Mughal.

7. On the reconfiguration and reactions of Mughal artists and patrons in response to Renaissance art, see my forthcoming book Mughal Occidentalism: Shifting Perspectives in Trans-Global Art.

8. Multiculturalism was not a new concept at the Mughal ateliers. From its early days, Indian, Central Asian, and Persian artists, painters, and calligraphers were working together at the royal workshops. See Michael Brand and Glenn Lowry, Akbar's India: Art from the Mughal City of Victory (New York: Asia Society, 1985), 13-32.

9. Govardhan, Sa'dī in the Rose Garden, fol. 6v, from an illustrated manuscript of Sa'dì's Gulistan, Mughal India (ca. 1630-45), ink, gold, and opaque watercolor on paper, $12.9 \times 6.7 \mathrm{~cm}$, Freer Gallery of Art, Washington, DC, inv. no. F1998.5.6. This manuscript is hereafter referred to in the text as the Freer Gulistan manuscript.

10. For further details about his life and work see Som Prakesh Verma, Mughal Painters and Their Work: A Biographical Survey (Delhi: Oxford University Press, 1994), 160-61. 
library in the sixteenth century. Sometime in the 1630s, the Timurid illustrations were painted over with Mughal ones. ${ }^{11}$

Written mostly in prose, the Gulistan centres on human notions of conflict, moral authority, political power, faith, love, and personal relations. Govardhan's painting shows the author, the poet Sa'dì, standing in a lush garden, facing a friend. But what appears to be a straightforward composition reveals itself to the discerning eye as a homoerotic image. The artist created a passionate representation studded with nuanced visual symbolism and sophisticated amorous allegory.

Did Govardhan's grasp of the intricacy of erotically charged Christian paintings ${ }^{12}$ inspire him to express emotional-mental ideas of male-male intimacy and sensuality? My analysis suggests that the Mughal artist built upon sixteenth-century European compositional elements and themes of Noli me tangere and Doubting Thomas, as well as the reader's understanding of the semantic relationship between text and image, to form subtle yet unmistakable allusions to sexuality and to arouse sexual anticipation in his audience. I will show later in the essay how the two very famous Christian iconographies could be linked to Govardhan's illustration.

The Gulistan, composed in 1258 for the rulers of Fars, contains several erotic-and, more specifically, homoerotic-stories. ${ }^{13}$ A number of anecdotes

11. On the date of the manuscript and the reasons for the Mughal overpainting see Abolala Soudavar, Art of the Persian Courts (New York: Rizzoli: 1992), 332-34. Convincingly, Massumeh Farhad argues for an earlier date for the Mughal paintings than the one provided by Soudavar. See her article, "Gulistan," in Beyond the Legacy: Anniversary Acquisitions for the Freer Gallery of Art and the Arthur M. Sackler Gallery, ed. Thomas Lawton and Thomas W. Lentz (Washington, DC: Smithsonian Institution, 1998), 148-49. In support of Farhad's argument see Mika Natif, “The Generative Garden: Sensuality, Man Love, and Eternity in Govardhan's Illustration of Sa'dī's Gulistān," in Eros and Sexuality in Islamic Art (Burlington, VT: Ashgate, 2013), 55n4.

12. For a discussion of such paintings see Leo Steinberg, The Sexuality of Christ in Renaissance Art and in Modern Oblivion (New York: Pantheon Books, 1983); Leo Steinberg, "The Metaphors of Love and Birth in Michelangelo's Pietàs," Studies in Erotic Art. ed. T. Bowie and C. Christenson (New York: Basic Books, 1970), 231-85.

13. Encyclopaedia Iranica, online ed., s.v. “Golestān-e Sađdi," by Franklin Lewis, accessed 10 December 2012, http://www.iranica.com/articles/golestan-e-sadi. For an English translation and the original Persian text see Sa'dī, The Gulistan (Rose Garden) of Sa'dī, bilingual English and Persian edition, trans. Wheeler McIntosh Thackston (Bethesda, MD: Ibex, 2008). Little is known about Sadỉs life. Educated in various Islamic religious institutions in Shiraz, Baghdad, and Syria, as well as by different shaykhs, the poet was supported by the governors of Shiraz to whom he presented some of his most famous works. Encyclopaedia of Islam, $2^{\text {nd }}$ ed., s.v. “Sa'dī, Abū 'Abd Allāh Musharrif al-Dīn b. Muṣlih Sa'dī, known 
deal with the subject of friendship and intimacy within a homoerotic context, and some of those have been interpreted as autobiographical. ${ }^{14}$ Chapter 5, entitled "On Love and Youth," evokes homoerotic conventions: the love of Sultan Mahmud of Ghazna for his slave boy Ayaz; the reversal of the power relationship when a master has been charmed by his youthful male servant, an ascetic falls madly in love with another man, a teacher likes his handsome young student, and a judge from Hamadan is completely enamoured with the blacksmith's boy. Some of these homoerotic stories are told in the first person, starting with "I remember a night ..." or "I fell head over heels in love with someone ...," thus providing a personal account, a sense of first-hand experience. ${ }^{15}$ Sádī openly engaged in male-male relationships and wrote about his own lust, desire, and sexual experience with young men and boys. ${ }^{16}$ Ironically, this homoeroticism

as Shaykh Sa'di," by Richard Davis, accessed 6 January 2011, http://www.brillonline.nl/subscriber/ entry? entry=islam_SIM-6416. For the difficulties in establishing Sadī’s biography see Encyclopaedia Iranica, online ed., s.v. "Sa‘di,” by Paul Losensky, accessed 25 January 2014, http://www.iranicaonline. org/articles/sadi-sirazi.

14. See Minoo Southgate, "Men, Women, and Boys: Love and Sex in the Works of Sa'di," Iranian Studies 17 (Autumn 1984): 415, 417, 432; Encyclopaedia of Islam, s.v. "Sa'ì”; Sa'dī, The Gulistan (Rose Garden), vi-vii; John D. Yohannan, The Poet Sa'di: A Persian Humanist (Lanham, MD: University Press of America: Bibliotheca Persica, 1987), 77-80. On the debate regarding the usage of terms and definitions such as "homosexuality," "gay," and "same-sex relations" with respect to premodern Muslim societies, see Stephen O. Murray and Will Roscoe eds., Islamic Homosexualities: Culture, History, and Literature (New York: New York University Press, 1997), 3-7; Khaled El-Rouayheb, Before Homosexuality in the Arab-Islamic World, 1500-1800 (Chicago: University of Chicago Press, 2005), 5-6; Scott A. Kugle, Sufis \& Saints' Bodies: Mysticism, Corporeality, and Sacred Power in Islam (Chapel Hill: University of North Carolina Press, 2007), 184, 305; Joseph A. Massad, Desiring Arabs (Chicago: University of Chicago Press, 2007), especially chapter 3; Kathryn Babayan and Afsaneh Najmabadi, eds., Islamicate Sexualities: Translations across Temporal Geographies of Desire, Harvard Middle Eastern Monographs 39 (Cambridge, MA: Harvard University Press, 2008), ix-xiv.

15. See for example chapter 5 , stories $6,8,10,16$, ff. Southgate notes that "the pornographic writings, the secular love poems, and the homosexual anecdotes of the 'Gulistan' were written in the poet's youth" (Southgate, 415).

16.At the same time, according to Richard Davis, Sa'di stated that he was married twice. Encyclopaedia of Islam, s.v. "Sa'dī." Many of Sa'dīs ghazals (a poetic form composed of at least five couplets) contain sexual and homoerotic elements; see Ehsan Yarshater, "Love-Related Conventions in Sa'di’s Ghazals," in Studies in Honour of Clifford Edmund Bosworth, vol. 2, The Sultan's Turret: Studies in Persian and Turkish Culture, ed. Carole Hillenbrand (Leiden: Brill, 1999), 420-38. Sa'dì's numerous anecdotes about male-male relations, love poems to beautiful boys, and homoerotic stories have led most scholars to believe that the author indeed preferred males to females, sexually and otherwise. His preference for 
is perhaps more provocative in today's world than it appeared to Sadì's contemporary readers, who relished the religio-profane mélange of what may be autobiographic homosexual anecdotes, mystical stories, and devotional prose. ${ }^{17}$ Premodern Persian literature dealing with homoerotic themes was common and acceptable to various degrees, and some of the most renowned Persian poets wrote on such topics. For example, Sa'dỉs contemporary Jalāl al-Dīn Rūmī wrote poems about his complicated intimate love relations with his Sufi teacher Shams al-Din of Tabriz. ${ }^{18}$ This is not to say that male-male intimate sexual relations were not criticized in the premodern Muslim world; however, such relations were apparently not perceived as a threat to the social or political order at different times and in different places. $^{19}$

male lovers was clear to his Safavid audience (1501-1722), as he is portrayed in one illustration from the Bustan begging his beloved-a young man-to stay. Sa'dī, Bustan, fol. 20r, Safavid, Iran (illustrated ca. 1565), published in Soudavar, 175, fig. 66c. On the reliability of Sa'dìs autobiographical details, see Encyclopaedia of Islam, s.v. "Sa 'dī” and Encyclopaedia Iranica, online ed., s.v. "Sa‘di."

17. See Southgate, 432. It seems that the uneasiness around the homoerotic content of Sa'dìs work came from some of the nineteenth-century Europeans who translated the Gulistan into English, German, French, and Latin. They resolved the issue either by omitting the difficult sections or by changing the sex of the beloved. Lewis notes that in the case of the Gulistan, Edward Eastwick removed the unnerving sections dealing with pederasty in chapter 5, "for which he was charged with bowdlerizing the work" (Encyclopaedia Iranica, s.v. "Golestān-e Sa'di”). Yohannan points to James Ross as an example of a translator who performed an act of sex change on the beloved in the chapter "On Love and Youth." See Yohannan, 77-80. This uneasiness was not reserved only for Sadī; similarly problematic notions appeared in other homoerotic Persian poetry and prose. See Encyclopedia Iranica, s.v. "Homosexuality III: In Persian Literature," accessed 10 May 2009, http://www.iranicaonline.org/articles/homosexuality-iii.

18. On erotic premodern Persian poetry see Encyclopedia Iranica, online ed., s.v. "Iran: Classical Persian Literature," by Charles-Henri de Fouchécour, accessed 15 January 2011, http://www.iranicaonline.org/ articles/iran-viii2-classical-persian-literature. A fascinating interpretation of Rūmìss usage of homoeroticism is offered by Mahdi Tourage, Rumi and the Hermeneutics of Eroticism (Leiden: Brill, 2007). Kaoru Aoyagi's thorough analysis of Sufi sources deals with different views on erotic practices and the worship of God. See Aoyagi, “Transition of Views on Sexuality in Sufism: Al-Makkī, al-Ghazālī, and Ibn al-Arabī, Annals of the Japan Association of Middle East Studies 22 (2006): 1-20.

19. For a more thorough discussion of the various opinions and attitudes toward male-male intimate relations in the medieval and early modern Muslim world, see Everett K. Rowson, "The Categorization of Gender and Sexual Irregularity in Medieval Arabic Vice Lists," in Body Guards: The Cultural Politics of Gender Ambiguity, ed. Julia Epstein and Kristina Straub (New York: Routledge, 1991), 50-79; Rowson, “Two Homoerotic Narratives from Mamluk Literature: al-Safadi's Law'at al-shaki and Ibn Daniyal's alMutayyam," in Homoeroticism in Classical Arabic Literature, ed. Jerry W. Wright Jr. and Everett K. Rowson (New York: Columbia University Press, 1997), 158-91; Rowson, “Gender Irregularity as Entertainment: 
While modern scholars have analyzed the sexual and homoerotic content in Sadìs thirteenth-century Persian texts, ${ }^{20}$ the illustrations that accompany these works have not received the same attention from historians of Islamic art, and their erotic iconography has been largely ignored. Offering in-depth analysis of the texts, Minoo Southgate, Ehsan Yarshater, and Julie Scott Meisami discuss the various explicit and implicit sexual anecdotes and poems in Sadi's work, especially the homoerotic ones from the chapter "On Love and Youth" in the Gulistan. Yet there are no similar studies of the homoerotic illustrations for this chapter. ${ }^{21}$ Moreover, the fact that at least four of the six illustrations (which were made by different artists) in the Freer Gulistan manuscript clearly depict male-male passion reinforces the intention of Govardhan's homoerotic painting. ${ }^{22}$

The episode in the rose garden represents the moment that inspired the creation of the Gulistan: Sadì's motivation for writing the work itself. In this tale the author recalls that one day he was feeling depressed about his life and was contemplating retiring from the company of humankind and going into seclusion. His friend, who was trying to dissuade him from his hermitic decision, convinced Sadì to get out of the city and refresh his thoughts in a garden. Upon reaching an enchanting rose garden in bloom, the two men decided to spend a delightful spring night in that grove. The next morning, when they realized that they had to return to the city, Sa'in noticed that his companion had collected roses, basil, hyacinths, and herbs from the garden as souvenirs and mementos of the night they had spent together. The author approached his friend and said: "Flowers, as you know, do not last, and the garden has no fidelity. The wise have said, "What does not last is not worthy of attachment." The friend asked, "Then

\footnotetext{
Institutionalized Transvestism at the Caliphal Court in Medieval Baghdad," in Gender and Difference in the Middle Ages, ed. Sharon Farmer and Carol Braun Pasternack (Minneapolis: University of Minnesota Press, 2003), 45-72. See also El-Rouayheb, Before Homosexuality in the Arab Islamic World; Willem Floor, A Social History of Sexual Relations in Iran (Waldorf, MD: Mage Publishers, 2008), 283-332; Encyclopedia Iranica, s.v. "Homosexuality III: In Persian Literature."

20. See Yarshater, 420-38; Southgate, 413-52; Julie Scott Meisami, "The Body as a Garden: Nature and Sexuality in Persian Poetry," Edebiyat 6 (1995): 245-74; Homa Katouzian, Sadi: The Poet of Life, Love, and Compassion (Oxford: Oneworld, 2006); Encyclopaedia Iranica, s.v. "Golestān-e Sadi."

21. One exception is Natif, "The Generative Garden," 43-64.
}

22. Made by several artists, these three other illustrations are folio numbers $65 \mathrm{v}, 74 \mathrm{v}$, and $85 \mathrm{v}$, and their respective inventory numbers are F1998.5.65, F1998.5.74, and F1998.5.85. 
what is to be done?" Sa 'dī replied with a remarkable promise to his companion: "I may compose a book of a Rose Garden [Gulistan] whose leaves cannot be touched by the tyranny of the seasons, and whose delight will not be changed by time." The next segment of the story is calligraphed on the illustrated folio: "After I [Sa'di] said these words my friend threw away the flowers, and attached himself to my robe, saying: 'When an honorable man makes a promise he keeps it." 23 Thus we are witnessing Sa'dì's promise of what we might interpret as eternal love for his friend after they spent an unforgettable night in a flower-filled garden.

In numerous Persian poems, as well as in the Gulistan, the garden is a place of passion and desire, where the natural blends with the human, the floral with the corporeal. ${ }^{24}$ In medieval Persian poetry, the garden "is not a place of solitude," as Sa'dī states, and the setting frequently symbolizes love itself. ${ }^{25}$ The composition and imagery in Govardhan's illustration reflect this erotic meaning. Two trees reflect the bodily forms of Sa'dī and his companion, framing the physical intimacy of the moment. To borrow the words of Julie Meisami, it seems that, in Sa'dì's poem, "garden and body intermingle, act upon each other, take on qualities of each other. Both are objects of desire, potential sources of joy." ${ }^{26}$ Moreover, in Govardhan's painting we can identify botanically varied flowers, fragrant herbs, and trees that are symbolically sensual and that are linked to the desired features of the beloved: eyes like narcissi, cheeks like roses, and a turbaned head bowing down like a tulip. The artist presents the different flowers the friend has collected at the hem of his robe as visual metaphors of beauty and lust. A tall chinar tree on the right and perhaps a prunus tree in bloom on the left further augment the concept of a garden of love.

Thus we are not simply looking at an ordinary garden, a conventional background. Rather, Govardhan's garden is a sensual landscape that sets the tone for the erotically charged interaction of the figures. Consequently, the

\section{Sa'dī, Gulistān, 7. My italics.}

24. I am paraphrasing Julie Scott Meisami, “The Body as a Garden: Nature and Sexuality in Persian Poetry," Edebiyat 6 (1995): 246. She argues that "love itself may be a garden" (250). For a fascinating discussion on the symbolism of the rose and eternal love, see Meisami, "Allegorical Gardens in the Persian Poetic Tradition: Nezami, Rumi, Hafez," International Journal of Middle East Studies 17 (May 1985): 229-60, 243.

25. Sađīi, Gulistān, 8. Meisami, "Body as Garden,” 250.

26. Meisami, “Body as Garden,” 247. 
position from which the friend discharges the flowers (i.e., the groin area) evokes male ejaculation. The text does not tell us that the friend had collected flowers at the hem of his robe-this specific position and addition to the narrative is the interpretation of the artist.

By delineating the setting as a garden of love, Govardhan makes clear that he fully understands the subtext of Sadì's narrative, with its allusions to the amorous actions of the previous night. In premodern Islamic art, lovemaking scenes often take place in blooming groves; hence compositions of two lovers in a garden are quite common. For example, in a painting from the Shähnäma (Book of Kings) in the Nasser D. Khalili Collection, London (MSS 544, fol. 36r), Zāl and Rūdāba are shown celebrating their wedding night in a garden pavilion. Surrounded by attendants holding candles and trays of fruit, the couple are fondling each other and locked in an embrace. ${ }^{27}$ More explicit in its sexual content is a ceramic bottle (possibly made in Isfahan, in the seventeenth century) that shows a man and a woman copulating in an orchard..$^{28} \mathrm{~A}$ painting by Manohar (active ca. 1582-1620s) dated ca. 1597 features a garden scene in which a Mughal prince and one of his concubines lie together in bed, their bodies entwined..$^{29}$ Another composition portraying an amorous couple, this time amid trees and flowers, illustrates a Mughal prince, perhaps Prince Murād (b. 1570), closely embracing and about to kiss one of his wives or concubines in a garden. Dated about 1615, this work has been attributed to Govardhan. ${ }^{30}$

In neither the Gulistan illustration nor the text itself is there any direct mention revealing that the men have engaged in sexual activity. However, through the reference to a nocturnal tryst in a garden and the erotic trope of such rhetoric in Persianate literature and painting, which would be familiar to readers of the illustrated volume, we are drawn to believe that something sexual or physical occurred during the previous night between Sadi and his companion. It was this event that brought them to the emotional scene unfolding in

27. For a reproduction, see Eleanor Sims, Peerless Images: Persian Painting and Its Sources (New Haven, CT: Yale University Press, 2002), 244.

28. The bottle is at the Walters Art Museum, Baltimore, inv. no. 48.1120.

29. Freer Gallery of Art, Washington, DC, inv. no. F1929.80. A similar scene, painted in India ca. 161020, features a couple kissing and embracing under a tree. Cleveland Museum of Art, inv. no. 1971.91.

30. Los Angeles County Museum of Art, inv. no. M.83.1.6. Amina Okada identifies the couple as Emperor Jahangir and Nur Jahan. Okada, Indian Miniatures of the Mughal Court (New York: Abrams, 1992), 192, 196. 
front of our eyes in Govardhan's painting. In other words, the Gulistan text serves perhaps as a public memento of a post-coital adventure in the garden of love, and this is reflected in Govardhan's illustration.

While the Gulistan does not detail the erotic nature of the relationship between the two men, in this picture the friend acts like a lover to the older poet: he has a longing, amorous expression on his face, and he grabs Sadì's robe as if begging for love. Gazing deeply into the poet's eyes, the companion releases the flowers that he collected at the hem of his robe, mimicking ejaculation, as noted above. Moreover, his flowery, adorned turban is in the manner of the bachcha, the beautiful boys who were an object of passion and desire in Persian artistic and literary production (Figure 3.1). ${ }^{31}$ As he is not the handsome beardless youth one often finds in contemporary homoerotic compositions, the beautification of Sa'dỉ's friend with flowers embellishing his turban is a detail Govardhan added and is not part of the text. These nuances emphasize the erotic playfulness of the couple and the visual and emotional sensitivity of the artist, who uses every opportunity to better showcase the sexual and sensual experiences of his characters. By placing the figures in the context of the painting's sexual imagery, Govardhan allows the flowers to encode even more deeply the homoerotic rapport between the two men.

Interestingly, the artist shifts the relationship between the two men in his depiction of the scene. While the text describes Sa'di as the one who bequeaths the gift of an eternal Rose Garden composition to his friend, conversely, the illustration emphasizes the companion as making his flower offering to the poet, allowing the blossoms to settle at his feet. In response, Sa'di is sincerely engaged, though his body language is more subdued than that of his younger lover, and he seems calmer. Sa'di smiles softly, and with his right hand over his heart, he delicately leans forward to reach out to his friend, while his left hand guides the viewer to his groin. ${ }^{32}$ At the same time, there is a deep and meaningful exchange between the two men as they gaze into each other's eyes. The

31. On the subject of beautiful boys and sodomy in Persian literature, see Sirus Shamisa, Shahid-bazi dar Adabiyat-i Farsi (Tehran: Firdows Publications, 2002); Lloyd Ridgeon, "The Controversy of Shaykh Awḥad al-Dīn Kirmānī and Handsome, Moon-Faced Youths: A Case Study of Shāhid-Bāzī in Medieval Sufism," Journal of Sufi Studies 1 (2012): 3-30.

32. There is a crease in this area on the paper from which paint has flaked off. 
ocular intensity between them acts as an affirmation of their physical intimacy that may correspond to the notion of love entering the heart through the eyes. ${ }^{33}$

Although the text and the illustrated scene both depict the gift of flowers that prompted the poet to create an "eternal garden," the painting enriches the story by alluding more explicitly to the multifaceted nature of the two men's intimate relationship, which might have had a physical dimension. Govardhan's image builds on the poetic allusions by producing a comparable visual metaphor that employs specific compositional and iconographic imagery to articulate the erotic implications of the text. The painting gains its erotic quality from the sensuous associations carried by the pictorial elements in the composition.

Creating an erotic painting to illustrate Sa'dìs Gulistan was not always an artist's obvious choice. This text was widely copied and illustrated, especially during the sixteenth and seventeenth centuries, but the illustrators did not necessarily maintain the same emphasis as the text. With Sa'dỉs homoerotic stories in particular, not all illustrations reflect the sexual nature of the episodes and the emotional state of the characters. For example, the same manuscript that includes Govardhan's painting also includes an illustration of the tale of the qādi (judge) from Hamadan who is caught drunk in bed with the blacksmith's son. The artist, Lalchand (active in the seventeenth century), chose to depict the two characters in a post-coital moment rather than in flagrante delicto (Figure 4). ${ }^{34}$ In this image, the young man is completely dressed, sitting away from the $q \bar{a} d \bar{\imath}$, but in contrast to Govardhan's painting there is neither physical nor eye contact between the two men..$^{35}$ The composition also lacks the heightened emotional and sexual tension between the youth and the older man that is crucial to Govardhan's painting. Certain visual details, however, point to the physical closeness between the two protagonists and provide clues to their erotic activity, such as the night scene, the scattered wine bottles, and the broken cups. Yet in a different, slightly later illustration of the same moment in the story, painted by the artist Payag (active ca. 1595-1658), the amorous couple is portrayed lying in bed, embracing half naked, and there is a strong sense of erotic intimacy

33. The idea of sight inducing love and the relations between the eye and the heart is a common theme in Persian prose and poetry. Hence, Attar, Rumi, Hafiz, Nizami, and Sa'di write about the eye of love. See, for example, the stories about Shaykh San'an and the Christian Maiden, Layla and Majnun, and Bijan and Manijeh.

34. Sa'dī, Gulistan, chapter 5, stories 20, 119.

35. This painting is discussed in Soudavar, 338, fig. 136e. 
between the two figures. ${ }^{36}$ The contrast between these two images reveals different levels of congruence between image and text. Importantly, it shows that the highly erotic character of the narrative does not always galvanize similar treatment in the illustration. Evoking the same intensity and sexual mode in the composition of the painting as in the narrative is a conscious decision made by the artist or the patron who commissioned the manuscript. Of the six illustrations in this manuscript, at least four, including Govardhan's painting, are clearly dealing with male-male passion in a consciously erotic manner. ${ }^{37}$ It is also worth noting that in two early fifteenth-century illustrations of the opening story of the Gulistan, the emotional and erotic components are completely missing from the compositions, even though Sa'dì and his companion are portrayed as an old master and a young disciple conversing at night in the garden. ${ }^{38}$

What made it possible or desirable for Govardhan to portray such an erotic, expressive, and emotional depiction of the scene? It seems that the artist used European pictorial elements, translated them into a Mughal idiom, and created what would be considered in Islamic art to be a dramatic emotional image. More specifically, I would like to suggest that in his painting, Govardhan was reconfiguring Renaissance European images of the Noli me tangere ("Do not touch me") and Doubting Thomas topoi-negotiating the physical, sentimental, intellectual, and visual parallels between the episode in the rose garden and the two Christian scenes. Such images struck a chord on a formal, compositional, conceptual level and also allowed the artist to explore further issues of sense engagement and sensual experience.

36. This painting, previously in the Hashem Khosrovani Collection, is signed by Payag and dated ca. 1640. The painting is reproduced in Joseph M. Dye III, "Payag," in Master Artists of the Imperial Mughal Court, ed. Pratapaditya Pal (Bombay: Marg Publications, 1991), 133, fig. 15.

37. See note 23.

38. The earlier image shows a youth bringing flowers to Sa'dī. The painting is included in an anthology made for Iskandar Sultan in Shiraz, dated 1411, and is now in the Museu Gulbenkian, Lisbon, fol. 96r, inv. no. L.A. 161. See Priscilla P. Soucek, “The Manuscripts of Iskandar Sultan: Structure and Content," in Timurid Art and Culture: Iran and Central Asia in the Fifteenth Century, ed. Lisa Golombek and Maria Subtelny (Leiden: Brill, 1992), 116-31. A slightly later painting of Sa'dī and his younger companion conversing at night in the garden can be found in an illustrated Gulistan created in Herat in 1426-27 and now in the Chester Beatty Library, Dublin, fol. 3r., inv. no. P.119. The painting is reproduced in Robert Hillenbrand, "Message of Misfortune: Words and Images in Sa'dìs Gulistan," in Silk and Stone: The Art of Asia, Hali Annual Series 3, ed. Jill Tilden (London: Hali Publications, 1996), 36-37. 
How was this material made available to Govardhan, and who would have explained the theology behind these images? The two men in the garden entertain highly unusual body language for Islamic art. Nothing of this sort can be seen in other Gulistan scenes or in illustrations of other texts from the sixteenth and early seventeenth centuries. However, following the more systematic encounters of Mughal artists with European prints and painting beginning in the 1580s, we find somewhat similar gestures in Mughal paintings dating from the early part of the seventeenth century. These materials could have been available for court artists such as Govardhan through the royal library, where some European books, paintings, prints, and drawings were kept. ${ }^{39}$ Hence Johannes Sadeler's engraving of the Noli me tangere (after Maarten de Vos) from 1580;0 Albrecht Dürer's engraving of the same subject from his woodcut series Small Passion (ca. 1512);11 or woodcuts made after Dürer, such as Marcantonio Raimondi's engraving of the Noli me tangere (ca. 1500-34), ${ }^{42}$ could all have been part of the traffic of images between East and West. ${ }^{43}$

Early modern European missionaries often used images of Doubting Thomas to assist them in their work of converting nonbelievers to embrace Christianity. ${ }^{44}$ The use of these images would have been particularly apt in

39. Several scholars have hypothesized about the European object holdings at the Mughal court. See, for example, Ebba Koch, "Netherlandish Naturalism in Imperial Mughal Painting," Apollo 152.465 (2000): 29-37; Brand and Lowry, Akbar's India, 87-106.

40. The print was offered for sale in 2012 by Schmidt Kunstauktionen, Dresden, Germany.

41. Erin Benay argues for a possible connection between a very similar painting of Doubting Thomas by Cima (ca. 1502-04, National Gallery, London) and Dürer's woodcut of the same subject from the Small Passion (1510-11). She also suggests a possible link between Dürer's print and a bronze tondo that Raphael designed for a chapel in Santa Maria della Pace. Erin Benay, “The Pursuit of Truth and the Doubting Thomas in the Art of Early Modern Italy" (PhD dissertation, Rutgers University, 2009), 106n105, 209-10.

42. The engraving is housed at the Metropolitan Museum of Art, acc. no. 17.37.265.

43. On the printed and painted material that reached India, see, for example, Milo Cleveland Beach, "The Gulshan Album and Its European Sources," Bulletin of the Museum of Fine Arts 63 (1965): 63-91; Sheila R. Canby, "Europe in India-Paintings, Drawings, and Ivories from the British Museum," Eastern Art Report 4 (1996): 45-49; Bailey, Jesuits and the Grand Mogul; Ebba Koch, "Netherlandish Naturalism in Imperial Mughal Painting."

44. Benay, 187-270; Antonio Monserrate, The Commentary of Father Monserrate, S.J. on his journey to the court of Akbar, trans. J. S. Hoyland; annot. S. N. Banerjee (New Delhi: Asian Educational Services, 1992), 36-37, 49. 
India, since St. Thomas is credited with having converted the subcontinent. ${ }^{45}$ Unfortunately, pinning down the specific images the Christian missionaries used is problematic because we have little physical evidence of what was actually brought to India or produced by Europeans or Christians already there. With respect to works on paper, not much has survived; therefore, our best evidence is Mughal paintings themselves. ${ }^{46}$ Moreover, since the Jesuits were still very much present at the Mughal court in the early seventeenth century, it would have been reasonable for Govardhan, who was linked to the royal workshops, to have had access to such resources as well as to people who could have explained the theological meaning of these images. In Jesuit sources, we are told that the Mughal Emperor Akbar (r. 1556-1605) brought his artists to the Jesuit chapel in Fatehpur Sikri to admire the beauty of special Christian images and ordered the artists to learn how to imitate them. ${ }^{47}$ Of course, because these kinds of testimonies were written by the Christian missionaries, we should read them quite critically; nevertheless, through them we can perceive the curiosity and porous relations among different facets and traditions at the Mughal court. In addition, by 1602 the stories of Mary Magdalene (the Noli me tangere) and Doubting Thomas appeared in a Persian text known as the Mirat al-quds (Mirror of Holiness), written for Emperor Akbar by the Jesuit missionary Father Jerome Xavier. ${ }^{48}$ Thus Govardhan would have had access to ample sources to learn about the Christian scenes he was appropriating.

On a conceptual level, in Govardhan's painting, as well as in Renaissance depictions of the Noli me tangere and Doubting Thomas, the sense of sight and the sense of touch are employed in the acquisition of knowledge and the

45. See The Golden Legend (Aurea Legenda), vol. 2, comp. Jacobus de Voragine (1275), trans. William Caxton (1483), ed. F. S. Ellis (London: Temple Classic 1900; repr. 1931), 62-67. Also available online at http://www.fordham.edu/halsall/basis/goldenlegend/GoldenLegend-Volume2.asp. See also Leslie Brown, The Indian Christians of St. Thomas: An Account of the Ancient Syrian Church of Malabar (Cambridge: Cambridge University Press, 1956, rev. ed. 1982).

46. For example, see the pasted European prints in the Gulshan Album. Beach, figs. 1-2.

47. On the life of Govardhan, see Som Prakesh Verma, Mughal Painters and Their Work: A Biographical Survey (Delhi: Oxford University Press, 1994), 160-61. For Mughal artists making copies of European images, see Pierre du Jarric, Akbar and the Jesuits: An Account of the Jesuit Missions to the Court of Akbar, trans. C. H. Payne (London, 1926), 168.

48. For the specific stories, see Pedro Moura Carvalho, Mir'ät al-quds (Mirror of Holiness): A Life of Christ for Emperor Akbar: A Commentary on Father Jerome Xavier's Text and the Miniatures of Cleveland Museum of Art, Acc. No. 2005.145, trans. Wheeler M. Thackston (Leiden: Brill, 2011), 234-35. 
establishment of trust (and, in the Christian images, the reassurance of faith). ${ }^{49}$ Hence when Mary Magdalene sees Christ risen from his tomb, she witnesses his promise of salvation, just as Sadì's companion beholds the old master's pledge to create an eternal memory of the night they spent together in the garden. Conversely, Thomas the Apostle, who does not trust that what he sees is indeed the risen Lord, has to touch Christ's divine body in order to believe. In a similar way, Thomas, Mary Magdalene, and Sadỉs friend are all attempting to seek the truth through a sensory experience. In the case of Sadìs companion and the Magdalene, the sensory experience takes place outside, against a scenic landscape setting - more specifically, in a garden, as in Paolo Veronese's painting Noli Me Tangere (ca. 1580s). ${ }^{50}$ The Mughal and Italian artists use touch and the exchange of glances as the dramatic focal points of their compositions.

From a compositional point of view, Lisa Rafanelli further argues that in Titian's Noli Me Tangere (ca. 1514), Christ interacts with the Magdalene and does not reject her presence. ${ }^{51} \mathrm{He}$ bends toward her, "gazing directly and tenderly into her eyes." 52 Similarly, Sadī kindly receives his friend's touch, arching slightly forward toward his companion. Through his body language and tender look, he conveys his love for his friend. Furthermore, there is a sense of urgency in the forward leaning movement of both Titian's Magdalene and Sa'dì's companion.

Yet, the Mughal composition appears to blend the images of the Magdalene and Thomas, where the body language of Sa'di and his friend are imbued with conflicting notions of hesitation and promise, of doubt and eternal love. Amalgamation and hybridization of the two Christian iconographies are also evident in Francesco Salviati's painting The Doubting of St. Thomas (1543-47). ${ }^{53}$ The conceptual parallels between the themes of the Noli me tangere and Doubting Thomas did not necessarily yield similar iconographic representations, yet in his painting, Salviati seems to purposefully conflate

49. Lisa Marie Rafanelli, “The Ambiguity of Touch: St. Mary Magdalene and the 'Noli Me Tangere' in Early Modern Italy” (PhD dissertation, New York University, 2004); Erin Benay, "The Pursuit of Truth.” I would like to thank Lisa and Erin for their generosity and for discussing their work with me.

50. Paolo Veronese, Noli Me Tangere, ca. 1580s, oil on canvas, 67 x 97 cm, Musée de Grenoble, France.

51. Titian, Noli Me Tangere, ca. 1514, oil on canvas, 110.5 x $91.9 \mathrm{~cm}$, National Gallery of Art. Rafanelli, 236.

52. Rafanelli, 236-37.

53. Francesco de' Rossi (also known as Francesco Salviati and other names), The Doubting of St. Thomas, oil on canvas. 275 x $233 \mathrm{~cm}$, Musée du Louvre, Paris. 
the two scenes. Although Thomas has come to be identified with touching the body of Christ and probing the wound, the artist does not actually show him in physical contact with Christ. In fact, Salviati portrays Thomas as a bit hesitant, his body language echoing Mary Magdalene's. ${ }^{54}$ The similar synthesis of the two Christian iconographies as evident in the Mughal image attests to the erudite selectivities of Govardhan with respect to Christian Renaissance imagery.

Because touch or the desire to touch is associated with the impulses of lust, pleasure, and sex, these three scenes are further linked to erotic or latent erotic encounters. ${ }^{55}$ As Govardhan's figures strike remarkable body positions that are unusual in Persian and Indian painting, we may conclude that the erotic association acted as a visual catalyst, and that the inspiration for this particular body language in the Mughal illustration is not coming from the Persian-Muslim artistic tradition, but rather from a European one. Like Titian's Christ in Noli Me Tangere and Cima de Conegliano's Christ in his painting Incredulity of St. Thomas with Bishop Magno of Oderzo (1505), ${ }^{56}$ Govardhan's Sa'di draws the viewer's attention to his groin area: Christ does so by collecting his robe and touching his upper thigh, ${ }^{57}$ while Sa'dī points in that direction with his left hand. Rafanelli argues that in Titian's Noli Me Tangere, Christ's gesture reflects the Magdalene's improper desire to touch him; hence the attention Christ draws to his genitalia is linked to his return as well as to his healed earthly body and the "promise of the Incarnation." ${ }^{58}$ Notably, in Cima's painting of Doubting Thomas, Christ, with his resurrected and sacramental body, touches

54. Erin Benay and Lisa Rafanelli, Faith, Gender and the Senses in Italian Renaissance and Baroque Art (Burlington, VT: Ashgate, 2015), 12, 187.

55. For an interpretation of the latent erotic relations between Christ and Mary Magdalene and Christ and Thomas, see Rafanelli, 197, 223-59, 280-84. About touch in the Renaissance, see Elizabeth D. Harvey, Sensible Flesh: On Touch in Early Modern Culture (Philadelphia: University of Pennsylvania Press, 2003); Reimund Bieringer, Barbara Baert, and Karlijn Demasure, eds., To Touch or Not to Touch? Interdisciplinary Perspectives on the Noli me tangere (Leuven: Peeters, 2011). On the Islamic tradition, Encyclopaedia of Islam, s.v. "Hiss," by J. N. Mattock, accessed 12 October 2013, http://referenceworks. brillonline.com/entries/encyclopaedia-of-islam-2/hiss-SIM_2910.

56. Cima da Conegliano, The Incredulity of St Thomas with Bishop Magno of Oderzo, ca. 1505, tempera and oil on panel, $215 \times 151 \mathrm{~cm}$. Accademia, Venice.

57. Rafanelli, 237.

58. As a mortal woman with an unsavoury past, Mary Magdalene's desire to touch the divine body of the risen Christ is inappropriate. Rafanelli considers the attention to Christ's lower part of his body as linked to "traditional body hierarchy" and therefore "associated with earthly matters" (Rafanelli, 237). 
the evangelist's hand as Thomas probes the divine side wound..$^{59}$ In Govardhan's painting, erotica as a symbol of life force and creativity is also evident in the placement of the companion's hand on Sa'di's robe, around the crease at the upper thigh. As the companion and Sa'di meet each other's gaze, the friend appears to be sprouting flowers from the hem of his robe in response to the author's promise of eternal love and his declaration that their night together is his creative motivation for writing the Gulistan. Seeking physical contact that inspires awareness is thus evident in all three paintings.

The three paintings and their erotic (in)tensions are also connected through a shared trope: the depiction of a spiritual authoritative figure/teacher in an intimate relationship with a disciple/student. The depiction of Sadì as an old shaykh further enhances the religio-erotic notion in Govardhan's painting. With his white beard, turban, and long dress and robe, the elderly poet becomes identified with portrayals of religious figures, especially those from the Chishti order in Mughal India, thus creating a spiritual connection between the poet and his companion..$^{60}$ Similarly, Thomas is a disciple and the Magdalene is a follower of Christ, and their quest for truth also leads them to close physical and mental association with their spiritual teacher. In Muslim literature and thought, close and intimate relations between a mentor/teacher or a master ( $p i r)$ and his student/disciple ( $m u r i \bar{d}$ ) were rooted in Greek philosophical texts

59. On the sexuality of Christ's wound as vulva in a medieval text, see Wolfgang Riehle, The Middle English Mystics, trans. B. Standring (London: Routledge and Kegan Paul, 1981), 46. For a discussion of the visual nature of these concepts, see Martha Easton, "The Wound of Christ, the Mouth of Hell: Appropriations and Inversions of Female Anatomy in the Later Middle Ages," in Tributes to Jonathan J. G. Alexander: The Making and Meaning of Illuminated Medieval and Renaissance Manuscripts, Art, and Architecture, ed. Susan L'Engel and Gerald B. Guest, (London: Harvey Miller, 2006), 395-414. On the homoeroticism of Caravaggio's Doubting Thomas, see Leo Bersani and Ulysse Dutoit, Caravaggio's Secrets (Cambridge, MA: MIT Press, 1998).

60. See for example Bichitr's portrait of Mu'in al-Dīn Chishtī , ca. 1610-18, from the so-called Minto Album in the Chester Beatty Library, Dublin, fol. 36r, inv. no. In 07A.14. The painting is published in Elaine Wright et al., Muraqqa: Imperial Mughal Albums from the Chester Beatty Library, Dublin (Alexandria, VA: Art Services International, 2008), 290. See also Jahāngīr with Shaykh Salìm Chishtī, from the Gulshan Album, ca. 1610-15, now in the Museum für Islamische Kunst, Berlin, fol. 22r. Depictions of Sufi shaykhs and ulama (religious authorities or scholars) were common under the emperors Jahāngīr and Shāh Jahān, as the Chishti order grew stronger and gained religious and political power among the Mughal elite; see Annemarie Schimmel, Islam in the Indian Subcontinent (Leiden: Brill, 1980), 180. 
that had been translated into Arabic and Persian. ${ }^{61}$ Likewise, there are many instances in historical sources, prose, and poetry of a student falling in love with his teacher and bonding with him intellectually and socially. ${ }^{62}$ This trope soon became common in visual depictions as well: in two early fifteenth-century illustrations of the opening story of the Gulistan, Sa'di and his companion are clearly portrayed as an old master and young follower (murìd) conversing at night in the garden. ${ }^{63}$ Following this teacher-student homosocial topos, Govardhan, in a depiction that is perhaps self-referential, also portrays a companion's allegiance to an authoritative master and thus elicits reflection on the relationship between an older teacher/poet/shaykh and his student. ${ }^{64}$

To convey the intentionality of the relationship between Sa'ī and his friend, Govardhan conflated the themes of the Noli me tangere and Doubting Thomas-and, by doing so, he injected another dimension into the composition, creating a link between body and soul. His figures' body language is a fascinating mixture of supplication, despair, passion, and tranquility. The Mughal artist fully understood the relationships between Christ and Mary Magdalene and between Christ and Thomas; however, he crucially recoded and translated these ideas into his own idioms. Thus this is not a simple borrowing of visual elements but rather the interculturation of Renaissance iconography and technique into Mughal painting. In Govardhan's illustration of the opening scene of Sa'dìs Gulistan, the artist's nuanced representation brings forth the subtleties of Islamic erotic visual language. In such images we may examine links between verbal and visual metaphors, the symbolism of allegorical settings, and the conflation of various artistic traditions. Recognizing Govardhan's blending

61. On the translation movement initiated by the Abbasid caliphs, see Encyclopaedia of Islam, s.v. “Tardjama," by D. Gutas et al., accessed 10 October, 2012, http://referenceworks.brillonline.com/entries/ encyclopaedia-of-islam-2/tardjama-COM_1178?s.num=0\&s.f.s2_parent=s.f.book.encyclopaedia-ofislam-2\&s.q=tardjama.

62. For the complicated love relations between Jalāl al-Dīn Rūmī and his Sufi master Shams al-Dīn of Tabriz, see note 19 .

63. The earlier image shows a youth bringing flowers to Sa'di. The painting is included in an anthology made for Iskandar Sultan in Shiraz, dated 1411, and now in the Museu Gulbenkian, Lisbon, fol. 96r, inv. no. L.A. 161. See Priscilla P. Soucek, “The Manuscripts of Iskandar Sultan: Structure and Content," in Timurid Art and Culture: Iran and Central Asia in the Fifteenth Century, ed. Lisa Golombek and Maria Subtelny (Leiden: Brill, 1992), 116-31.

64. See Natif, “Generative Garden,” 52-54. 
of idioms from European Renaissance and Persian-Mughal art allows us to understand his "erotic motivation." ${ }^{65}$ His choice of eros as a symbol of intellectual and spiritual awakening reveals the intersection of physical intimacy and cognition and of early modern Mughal and European art.

65. These ideas resemble what Martha Nussbaum identifies in Plato's writing on the erotic relations between a teacher and a student and the link between eros, learning, knowledge, and the good. Nussbaum, The Fragility of Goodness: Luck and Ethics in Greek Tragedy and Philosophy, rev. ed. (Cambridge: Cambridge University Press, 2001), 200-33. For further connections between Govardhan's painting and Plato's Phaedrus, see Natif, “Generative Garden,” especially 52-54. 




Figure 1. Basawan, The Virgin and Child, 1590 (album page ca. 1610), Mughal India, opaque watercolour and gold on paper, $21.7 \times 13.7 \mathrm{~cm}$. Edwin Binney 3rd Collection, The San Diego Museum of Art, 1990.293, www.sdmart.org. 


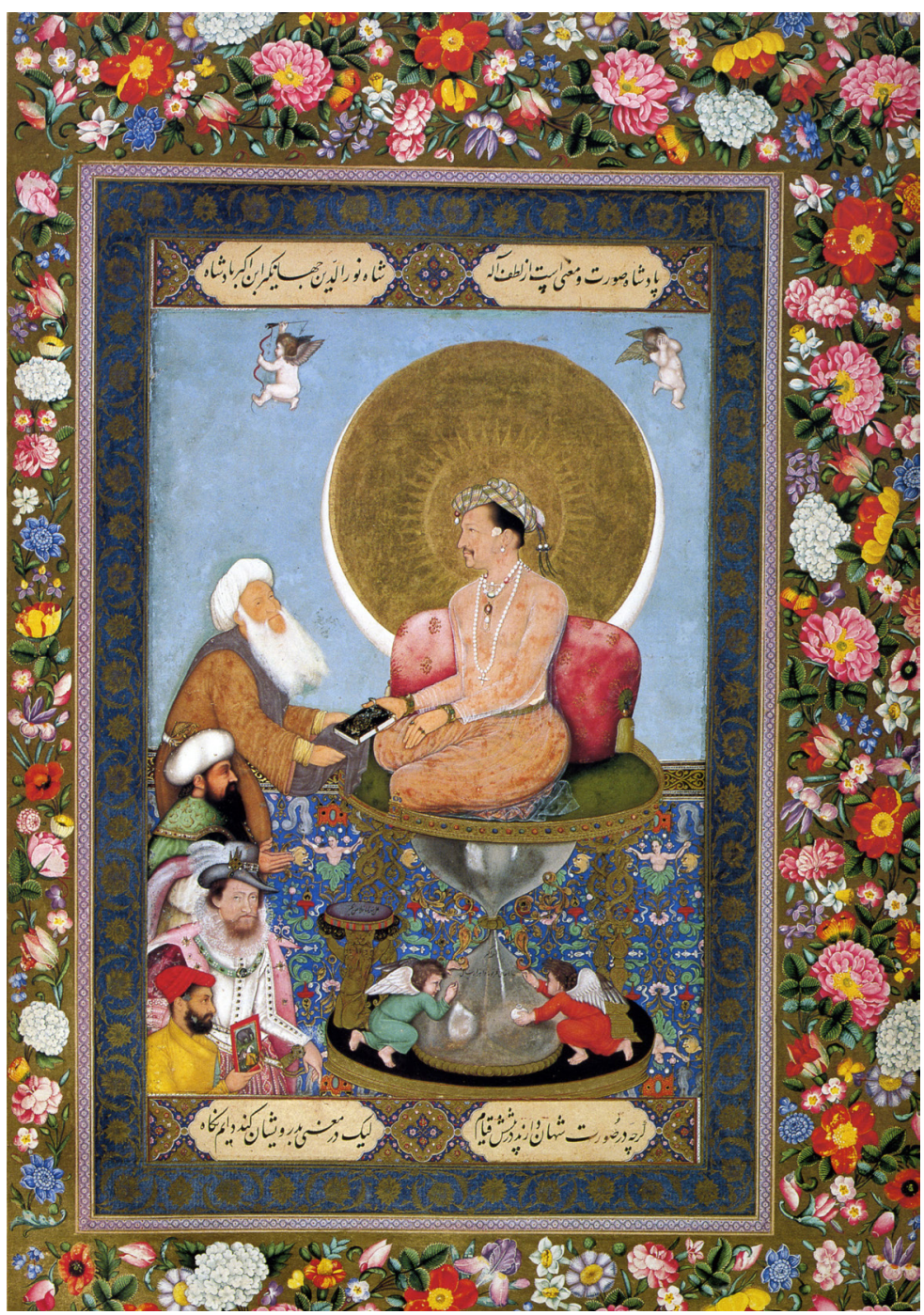

Figure 2. Jahangir Preferring a Sufi Shaikh to Kings, by Bichitr, ca. 1615-1618, Mughal India, from the St. Petersburg Album, margins 1747-48, opaque watercolour, ink, and gold on paper, 48.0 x $33.0 \mathrm{~cm}$, Freer Gallery of Art, Smithsonian Institution, Washington, DC, inv. no. F1942.15a. Photo: (C Freer Gallery of Art and Arthur M. Sackler Gallery. 




Figure 3. Sa'dī in the Rose Garden, by Govardhan, Gulistān, India, ca. 1630-45, Mughal India, ink, gold, and opaque watercolour on paper, 12.9 x $6.7 \mathrm{~cm}$, Freer Gallery of Art, Smithsonian Institution, Washington, DC, Gift of the Art and History Trust in honour of Ezzat-Malek Soudavar, inv. no. F1998.5.6. Photo: (c) Freer Gallery of Art and Arthur M. Sackler Gallery. 


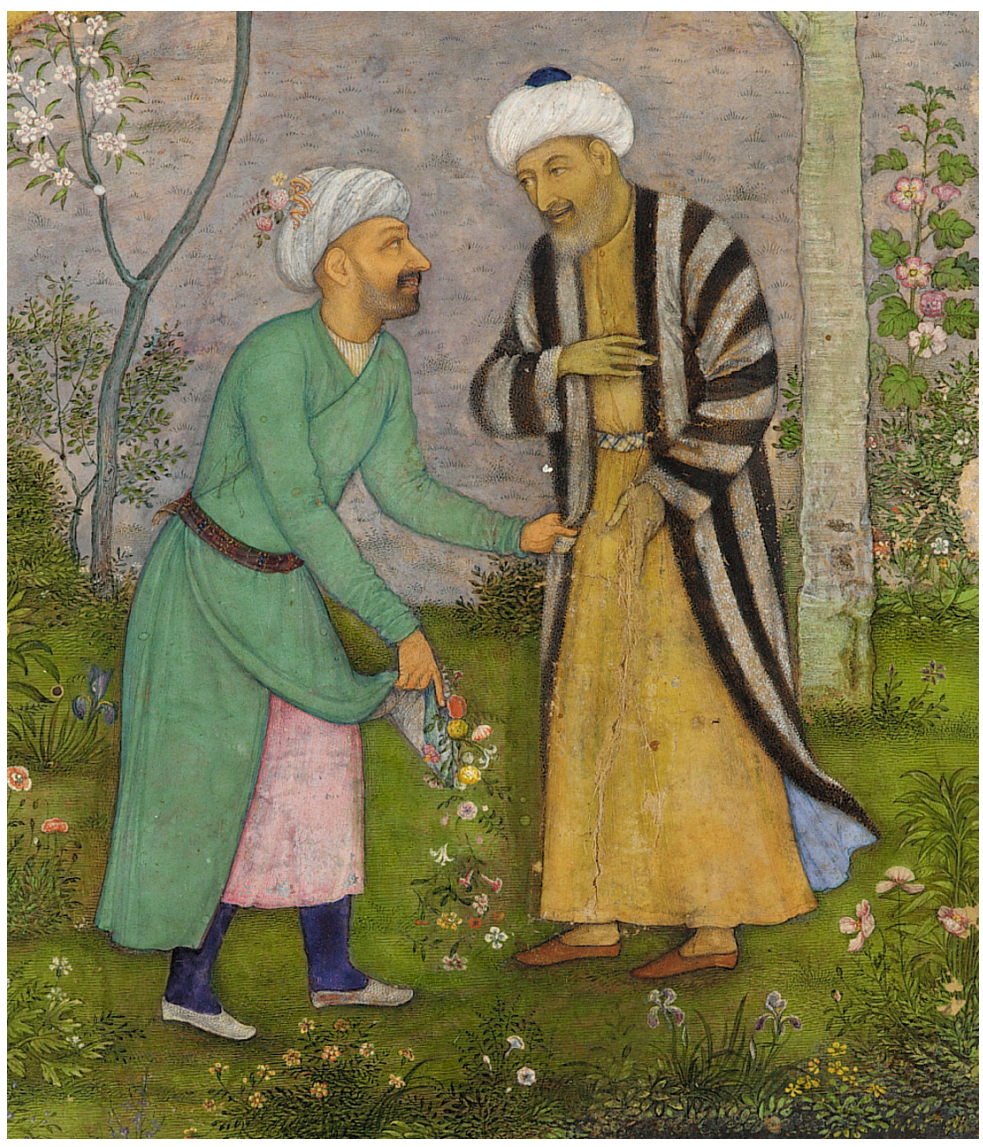

Figure 3.1. Detail of Sa'dī in the Rose Garden. 


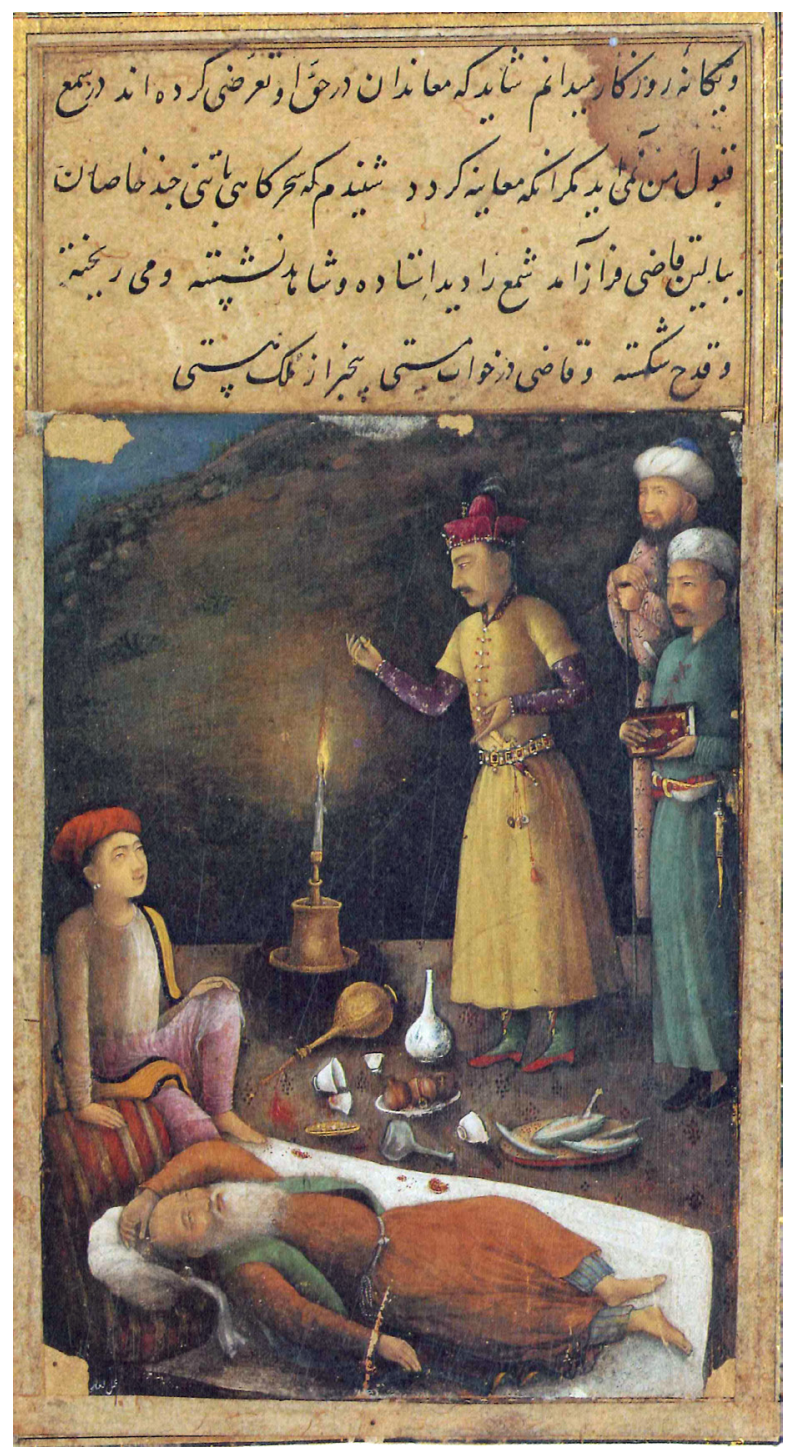

Figure 4. The Qazi of Hamadan in a drunken state, by Lalchand, Gulistān, India, ca. 1630-45, Mughal India, ink, gold, and opaque watercolour on paper, 24.6 x $16.0 \mathrm{~cm}$, Freer Gallery of Art, Smithsonian Institution, Washington, DC, Gift of the Art and History Trust in honour of Ezzat-Malek Soudavar, inv. no. F1998.5.74. Photo: (C) Freer Gallery of Art and Arthur M. Sackler Gallery. 